\title{
BEAS-2B ve A549 Hücre Hatlarında Hidatik Kist Sıvısının Apoptoz Yolağı Üzerine Etkisinin Değerlendirilmesi
}

\section{Evaluation of the Effect of Hydatid Cyst Fluid on the Apoptosis Pathway in BEAS-2B and A549 Cell Lines}

\author{
Ipek BAYSAL ${ }^{1}(I D)$, Serra ÖRSTEN ${ }^{2}($ ID) \\ ${ }^{1}$ Hacettepe Üniversitesi, Sağlık Hizmetleri Meslek Yüksekokulu, Eczane Hizmetleri Programı, Ankara. \\ ${ }^{1}$ Hacettepe University, School of Health Services, Pharmacy Services Programme, Ankara, Turkey. \\ ${ }^{2}$ Hacettepe Üniversitesi, Sağlık Hizmetleri Meslek Yüksekokulu, Tıbbi Laboratuvar Programı, Ankara. \\ ${ }^{2}$ Hacettepe University, School of Health Services, Medical Laboratory Programme, Ankara, Turkey.
}

Makale Atıfı: Baysal I, Örsten S. BEAS-2B ve A549 hücre hatlarında hidatik kist sıvısının apoptoz yolağı üzerine etkisinin değerlendirilmesi. Mikrobiyol Bul 2021;55(2):248-255.

\section{ÖZ}

Bazı patojen mikroorganizmalar konak hücresinde karsinogenez öncüsü enflamatuvar sürecin aktivasyonuna yol açmaları nedeniyle kanser gelişimi ile ilişkilendirilmiştir. Diğer bazı patojenlerin ise, anti-neoplastik immün yanıt oluşturarak tümör oluşumunu engellediği ve kanser gelişimini durdurduğu bildirilmiştir. Kistik ekinokokkoz (KE) veya kist hidatik (KH), Echinococcus granulosus sensu lato (sl)'nun larva formunun insanlarda neden olduğu zoonotik bir enfeksiyondur. E.granulosus enfeksiyonu ile kanser arasında negatif bir korelasyon olduğu bildirilmiş, direkt ve/veya indirekt olarak E.granulosus enfeksiyonunun anti-kanser etkisi olabileceği öne sürülmüştür. Ancak, bu etkinin moleküler mekanizmaları belirsizliğini korumaktadır. Bu çalışmada, E.granulosus kaynaklı kist sıvısı uygulamasının sağlıklı insan akciğer epitelyal (BEAS-2B) ve insan akciğer adenokarsinom (A549) hücre hatlarında hücre proliferasyonu ve bazı apoptotik gen (BCL-2, p53 ve BAX) ekspresyonları üzerine etkisinin değerlendirilmesi ile E.granulosus kist sıvısının olası anti-kanser etki mekanizmasının altında yatan moleküler mekanizmanın aydınlatılması amaçlanmıştır. E.granulosus kist sıvısının hücre proliferasyonuna ve apoptotik gen ekspresyonları üzerine etkisini değerlendirmek amacıyla sırasıyla hücre proliferasyonu deneyi (XTT) ve gerçek zamanlı polimeraz zincir reaksiyonu (Rt-PCR) gerçekleştirilmiştir. Hidatik kist sıvısı uygulamasının ardından hücre proliferasyonu açısından herhangi bir değişiklik saptanmamıştır. İstatistiksel olarak anlamlı olmak üzere, BCL-2 gen ekspresyonunda azalma (> 90 kat), p53 gen ekspresyonunda ise artış (> 1.2 kat) saptanmıştır. BAX gen ekspresyonu açısından anlamlı bir değişiklik tespit edilmemiştir. Bu çalışma ile hidatik kist sıvısı uygulamasının direkt olarak hücre ölümüne neden olmadığı; apoptoza karşı dirençli olan A549 hücre hattını apoptoza duyarlı hale getirdiği ilk kez gösterilmiş ve hidatik kist sıvısının apoptotik yolaktaki olası mekanizmasına ışık tutulmuştur.

Anahtar kelimeler: Echinococcus granulosus; hidatik kist sIVIsI; kanser; apoptoz.

\section{ABSTRACT}

Some of the pathogenic microorganisms have been associated with cancer due to the activation of cancer precursors in the host because of the inflammatory processes. Additionally, some other pathogens 
prevents the tumor formation by creating an anti-neoplastic immune response which has been reported to stop the development of cancer. Cystic echinococcosis (CE) or cyst hydatid disease (CHD) is a zoonotic infection caused by the larval form of Echinococcus granulosus sensu lato in humans. It has been reported that there is a negative correlation between E.granulosus infection and cancer and it has been suggested that direct and/or indirect E.granulosus infection may have an anti-cancer effect. However, the molecular mechanisms of this effect still remains unclear. The aim of this study was to evaluate the effect of hydatid cyst fluid administration on cell proliferation and expression of some apoptotic genes (BCL-2, p53 and BAX) in human healthy lung epithelial (BEAS-2B) and human lung adenocarcinoma (A549) cell lines and understanding the molecular mechanism underlying the possible anti-cancer action mechanism of hydatid cyst fluid. In order to evaluate the effect of hydatid cyst fluid on cell proliferation and apoptotic gene expression, cell proliferation assay (XTT) and real-time polymerase chain reaction (Rt-PCR) were performed, respectively. After the application of hydatid cyst fluid, there was no change in the cell proliferation. A statistically significant decrease in BCL-2 gene expression (> 90 fold) and an increase in p53 gene expression (> 1.2 fold) were found. No significant change in BAX gene expression was detected. In this study, it was found that the application of hydatid cyst fluid did not directly cause cell death but it has shown for the first time to sensitize the A549 cell line, which is resistant to apoptosisand shed light on the possible mechanism of hydatid cyst fluid in the apoptotic pathway.

Keywords: Echinococcus granulosus; hydatid cyst fluid; cancer; apoptosis.

\section{Giriş̧}

Enfeksiyonlar ve patojen kaynaklı enflamasyonun genellikle kanser gelişimi lehine olduğu ve dünya çapında tüm kanser olgularının tahminen \%15.6'sının patogenezinde enfeksiyon etkenlerinin rolü bulunduğu düşünülmektedir ${ }^{1-3}$. Helmintler, konak üzerinde kanserojen etkileri nedeniyle araştırılan mikroorganizmalardır. Bu bağlamda Schistosoma japonicum, karaciğer ve kolorektal kanser için bir risk faktörü olarak değerlendirilirken, Clonorchis sinensis ve Opisthorchis viverini'nin kolanjiyokarsinoma etkeni olduğu kabul edilmektedir ${ }^{4}$. Buna karşın, kanser gelişimini tetiklemenin aksine, belirli patojen türlerin kanser gelişim riskini azaltabileceği veya tümör gerilemesini kolaylaştırabileceğine dair kanıtlar bulunmaktadır². Bu verileri destekler nitelikte Echinococcus granulosus, Trichinella spiralis ve Strongloides stercoralis gibi parazitlerin anti-kanser aktivitesini gösteren çalışmalar yayımlanmıştır ${ }^{5,6}$.

Kistik ekinokokkoz (KE) veya kist hidatik $(\mathrm{KH})$, E.granulosus sensu lato'nun larva formunun insanlarda neden olduğu zoonotik bir enfeksiyondur ${ }^{7}$. KE, özellikle kırsal alanlarda, insanların hayvancılıkla aktif olarak ilgilendiği ve köpeklerle yakın temasta bulunduğu Avustralya, Asya, Güney Amerika ve Türkiye'nin de dahil olduğu Akdeniz ülkelerinde sıklıkla görülmektedir $^{8-10}$. Dünya Sağlık Örgütü (DSÖ)'ne göre KE, 2050 yılına kadar kontrol altına alınması ve elimine edilmesi gereken tropikal hastalıklardan biri olarak bildirilmiştir ${ }^{11}$. Hastalık her zaman asemptomatik başlangıçlı olup yıllarca sessiz olarak kalabilmektedir ${ }^{12}$. Semptomatik seyreden olgularda ise klinik semptomlar çeşitlilik göstermekle birlikte hastalığa özgü değildir $^{13}$. E.granulosus'un kanser ile olan ilişkisi konusunda çelişkili raporlar bulunmasına karşın, çoğu çalışma kanser gelişimini azalttığını savunmaktadır ${ }^{5}$. Türkiye'de gerçekleştirilen bir retrospektif çalışmada KE hastalarında kanser prevalansının anlamlı derecede düşük olduğu bildirilmiştir ${ }^{14}$. Literatürde, E.granulosus'un direkt veya indirekt olarak anti-kanser etki gösterebileceği, kist sıvısının immünoterapötik ajan olarak kansere karşı kullanılabileceği ortaya atılmıştır ${ }^{5}$. Birçok çalışma, E.granulosus enfeksiyonunun anti-kanser etkisine yoğunlaşmış olmasına karşın altta yatan moleküler mekanizmalar hala belirsizdir. Bu çalışmada, 
hidatik kist sıvıSı uygulamasının sağlıklı insan akciğer epitelyal (BEAS-2B) ve insan akciğer adenokarsinom (A549) hücre hatlarında hücre proliferasyonu ve bazı apoptotik gen (BCL2, p53 ve BAX) ekspresyonları üzerine etkisinin değerlendirilmesi; hidatik kist sıvısının olası anti-kanser etkisinin altında yatan moleküler mekanizmanın aydınlatılması amaçlanmıştır.

\section{GEREÇ ve YÖNTEM}

Bu çalışma için, ticari olarak elde edilen hücre hatları kullanılarak hücre kültürü ve mezbahadan elde edilen hidatik kist sıvısı kullanılmış olması nedeniyle, etik kurul onayı gerekmemektedir.

\section{Hücre Kültürü Uygulaması}

Çalışma kapsamında, A549 insan akciğeri adenokarsinom hücre hattı (ATCC ${ }^{\circledR}$ CCL$185^{\mathrm{TM}}$ ) ve BEAS-2B sağlıklı insan akciğeri epitelyal hücre hattı (ATCC ${ }^{\circledR}$ CRL-9609TM) kullanıldı. A549 ve BEAS-2B hücreleri antibiyotiklerle desteklenen $(100 \mathrm{U} / \mathrm{ml}$ penisilin, $100 \mathrm{lg} /$ $\mathrm{ml}$ streptomisin), \%10 oranında fetal sığır serumu (FBS) içeren DMEM/F12 besiyeri (tam besiyeri) ile süspanse edilerek $37^{\circ} \mathrm{C}^{\prime}$ de $\% 5 \mathrm{CO}_{2}$ içeren nemli atmosferde inkübe edildi.

\section{Hidatik Kist Sıvısı İncelemesi}

Konya iline bağlı mezbahalarda, 01.03.2018-01.07.2019 tarihleri arasında hayvan kesimleri sonucu hidatik kisti olduğu belirlenen karaciğerlerden aseptik koşullarda steril şırınga ile kist sıvısı aspire edildi. Kist sıvısı, kullanılana kadar $-80^{\circ} \mathrm{C}^{\prime}$ de saklandı. E.granulosus sl. tür doğrulaması ve genotip tayini amacıyla, kist sıvısı çözdürüldükten sonra 4000 rpm'de 15 dakika santrifüj edilip, çökelti kısmından $200 \mu$ l alınarak DNA izolasyonu yapıldı. DNA izolasyonu için ticari bir kit olan "Thermo Blood and Tissue DNA Extraction Kit (Qiagen, Hilden, Almanya)" üretici firma yönergeleri doğrultusunda kullanıldı. Elde edilen DNA, mitokondriyal bir gen olan sitokrom oksidaz 1 (mt-CO1) geninin 875 baz çiftlik bölgesini hedefleyen (F:5'- TTG AAT TTG CCA CGT TTG AAT GC-3' ve R:5' - GAA CCT AAC GAC ATA ACA TAA TGA-3') primer seti kullanılarak amplifiye edildi ${ }^{15}$. Elektroforezde pozitif olduğu gözlenen amplikonlar, DNA dizi analizine alındı ve elde edilen sonuçlar BLAST algoritmasına göre değerlendirildi.

\section{Hücre Proliferasyonu Deneyi (XTT)}

XTT hücre proliferasyonu deneyi, herhangi bir in vitro modelde hücre proliferasyonunun indüksiyonu ve inhibisyonunun incelenmesine olanak vermektedir. Deney, XTT'nin mitokondride üretilen NADH tarafından trans-plazma membran elektron taşıma sistemi ve bir elektron aracılığı ile ekstraselüler olarak indirgenmesine dayanmaktadır. XTT'nin indirgenmesi, ek bir çözücü ajana olan ihtiyacı ortadan kaldırarak doğrudan kültür ortamı içinde suda çözünür bir formazan üretmektedir. Bu şekilde, formazan 450 nm'de absorbans vererek hücrenin canlılığı ile ilgili bilgi verir. Bu çalışmada hidatik kist sıvılarının BEAS-2B ve A549 hücre hatlarının proliferasyonu üzerindeki etkilerinin saptanabilmesi için XTT deneyi kullanılmıştır. Doksan altı kuyucuklu hücre kültürü plaklarının her bir kuyucuğuna yaklaşık $5 \times 10^{4}$ hücre tam besiyeri ile ekildi. Değiş̧ik hacimlerdeki $(10,15$ veya $20 \mu \mathrm{l}$ ) hidatik kist sıvıları ile muamele edildikten sonra hücreler 24 saat $37^{\circ} \mathrm{C}^{\prime}$ de 
inkübe edildi. İnkübasyon süresinin bitiminde kuyucuk başına $50 \mu \mathrm{l}$ XTT çözeltisi eklendi ve ardından hücreler 2 saat süreyle $37^{\circ} \mathrm{C}^{\prime}$ de tekrar inkübasyona bırakıldı. İnkübasyon sonrasında plaka, $450 \mathrm{~nm}$ 'de plaka okuyucuda okundu. Sonuçlar kontrol grup değerleri kullanılarak standardize edildi. XTT deneyi en az n= 3 olacak şekilde gerçekleştirildi.

\section{Gerçek Zamanlı Revers Transkriptaz Polimeraz Zincir Reaksiyonu (rRT-PCR)}

BEAS-2B ve A549 hücreleri 6 kuyucuklu plakalara tam besiyeri içinde yaklaşık $3 \times 10^{5}$ hücre/kuyucuk olacak şekilde ekilmiş ve 24 saat inkübasyon sonrasında A549 ve BEAS-2B hücre hatlarına hidatik kist sıvıları uygulanmış ve 24 saat $37^{\circ} \mathrm{C}^{\prime}$ de inkübe edildi. Uygulama işlemini takiben, hücrelerden total RNA, ekstraksiyon kiti ile üretici firmanın yönergeleri doğrultusunda izole edilmiştir. Komplementer DNA (cDNA) $1 \mu \mathrm{g}$ total RNA'dan ters transkriptaz kullanılarak sentezlenmiştir. Bu işlem "Invitrogen SuperScript ${ }^{\mathrm{TM}}$ II Reverse Transcriptase" kiti üretici firma yönergeleri doğrultusunda $100 \mathrm{U}$ superscript II, $0.25 \mu \mathrm{g}$ "random" primer, 0.5 mm dNTP, $5 \mathrm{~mm}$ DTT, $32 \mathrm{U}$ RNaz inhibitörü varlığında 60 dakika $42^{\circ} \mathrm{C}^{\prime}$ de son hacim $20 \mu \mathrm{l}$ olacak şekilde RT tamponu içinde gerçekleştirilmiştir. Örneklerde kontaminasyon olmadığı negatif kontroller ile doğrulanmıştır. RT-PCR analizi 96 kuyucuklu plaklar ve SYBR Green PCR karışımı kullanılarak ViiA 7 RT-PCR (Applied Biosystems) sistemi ile gerçekleştirildi. Amplifikasyon reaksiyonu $25 \mu \mathrm{l}$ hacimde üretici firmanın önerileri doğrultusunda 1/5 oranında seyreltildi; $5 \mu$ lörnek varlığında üçlü kontrol sistemi ile gerçekleştirildi. Her deneyde araştırılan genin değeri, iç kontrol genin ("housekeeping gene"; GAPDH) değerine oranlanarak normalize edildi. Kullanılan ileri ve geri yönlü primer çiftlerinin tamamı Tablo I'de gösterilmiştir.

\section{Dizi Analizi}

Hidatik kist sıvısından elde edilen DNA amplifikasyonu sonucu dizi analizi gerçekleştirildi. Dizi analizi sonucu, BLAST algoritmasına göre \%100 oranında benzerlik göstererek E.granulosus sensu stricto (G1 genotipi) olarak belirlendi.

\section{BULGULAR}

Hidatik kist sıvısı uygulanmış sağlıklı ve akciğer kanser hücreleri için XTT sonuçları Şekil 1 'de verilmiştir. Değerlendirme sonucunda, kist sıvısının konsantrasyondan bağımsız olarak hücre proliferasyonu üzerine anlamlı bir etkisinin olmadığı tespit edilmiştir.

\begin{tabular}{ll}
\hline \multicolumn{2}{l}{ Tablo I. Çalışmada Kullanılan Primer Dizileri } \\
\hline Primerler & Diziler \\
\hline \multirow{3}{*}{ GAPDH } & F: 5'-ATG GGC AGC CGT TAG GAA A-3' \\
& R: 5'-GCA TCG CCC CAC TTG ATT TT-3' \\
BAX & F: 5'- CCC GAG AGG TCT TTT TCC GAG-3' \\
& R: 5'- CCA GCC CAT GAT GGT TCT GAT-3' \\
BCL-2 & F: 5'- GGT TGG GGT CAT GTG TGT GG-3' \\
& R: 5'- CGG TTC AGG TAC TCA GTC ATC C-3' \\
P53 & F: 5'- CAG CAC ATG ACG GAG GTT GT-3' \\
\end{tabular}




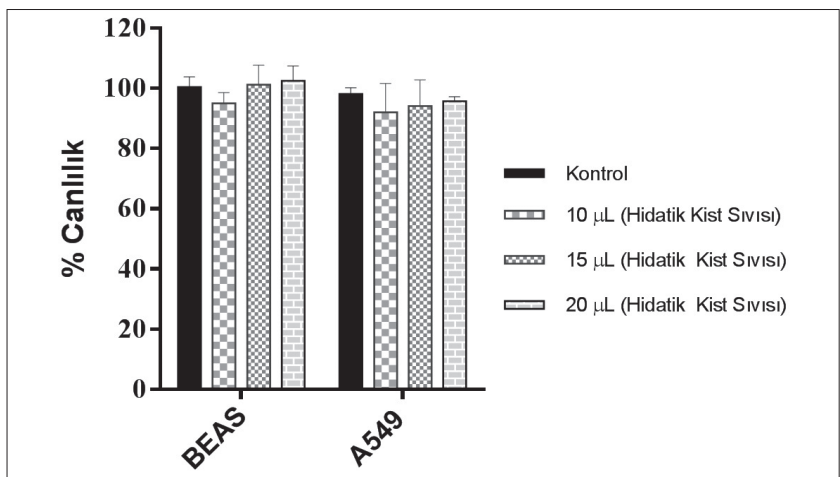

Şekil 1. Hidatik kist sıvısı uygulanmış BEAS-2B ve A549 hücre hatlarının XTT sonuçları.

Hidatik kist sıvıSı uygulanmış hücre hatları apoptotik yolakları kontrol eden genler olan BAX, BCL-2 ve p53 ekspresyonları açısından değerlendirilmiştir. Uygulama öncesi ve sonrası bağıl gen ekspresyon düzeyleri Şekil 2'de verilmiştir.

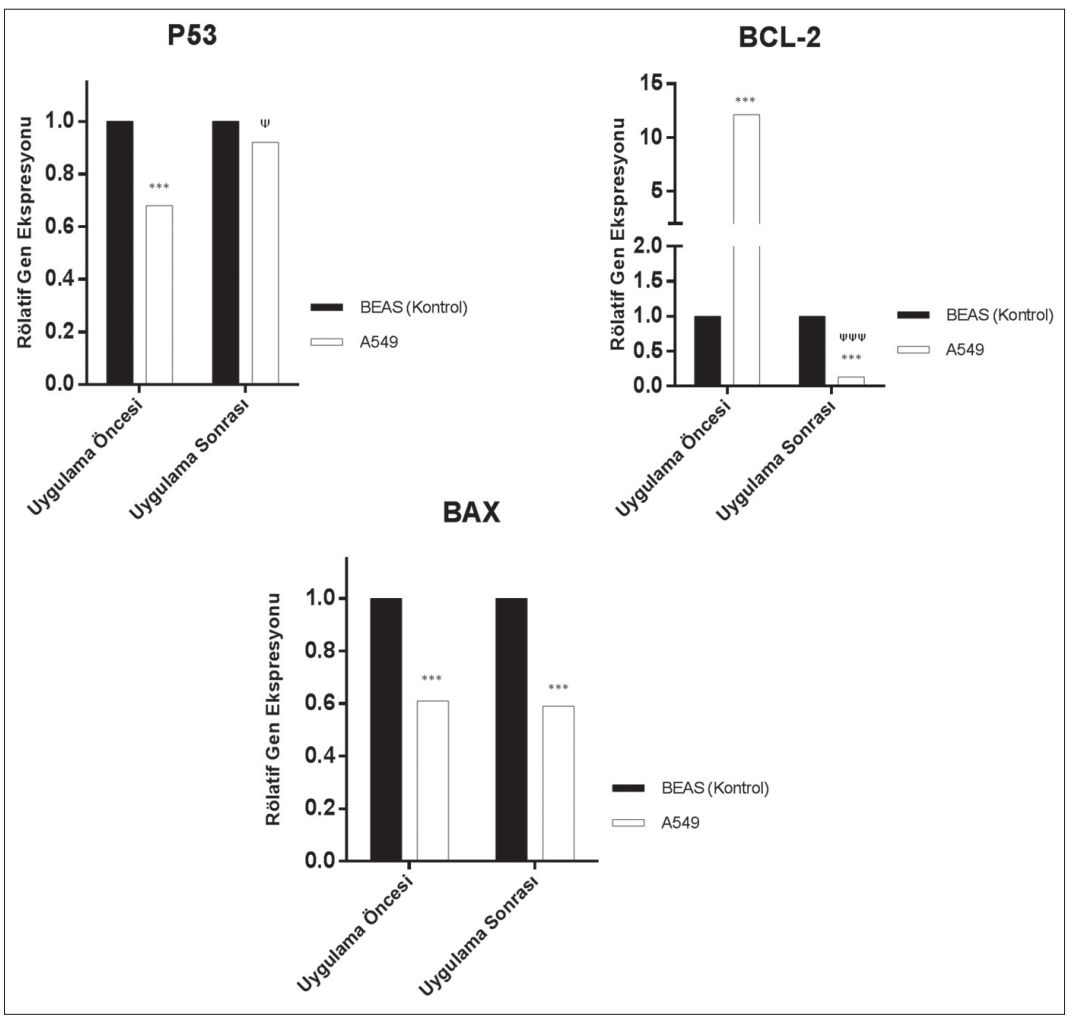

Şekil 2. BEAS-2B ve A549 hücre hatlarının kist sIVISı uygulaması öncesi ve sonrası $B A X, B C L-2$ ve p53 bağıl gen ekspresyonlarını gösterir grafikler $\left({ }^{* *} p<0.001\right.$ BEAS-2B kontrole karşı, $\Psi \Psi \Psi p<0.001, \Psi P<0.05$ uygulama öncesi A459'a karşı). 
Değerlendirme sonucunda, hidatik kist sıvısı uygulamasının ardından BAX gen ekspresyonu düzeyinde anlamlı bir değişiklik görülmemiştir. İstatistiksel olarak anlamlı olmak üzere, BCL-2 gen ekspresyonunda azalma tespit edilirken (> 90 kat), p53 gen ekspresyonunda artış (> 1.2 kat) saptanmıştır. BEAS-2B hücrelerinde uygulama sonrası apoptotik genler düzeyinde anlamlı bir değişiklik görülmemiştir.

\section{TARTIŞMA}

E.granulosus ile kanser arasındaki ilişki hala belirsizliğini korumakla beraber literatürde konuyla ilgili çelişkili raporlar bulunmaktadır. KE enfeksiyonu Türkiye için yüksek insidansIı parazitik bir enfeksiyon olmasına karşın ülkemizde gerçekleştirilen retrospektif bir çalışmada, KE enfeksiyonu insidansının solid tümörlü hastalarda istatistiksel olarak anlamlı derecede düşük olduğu bildirilmiştir ${ }^{14}$. Kıbrıs'ta yürütülen benzer bir retrospektif çalışmada ise tam tersi bir sonuç bildirilmiştir ${ }^{16}$. Öte yandan farklı grupların yürüttüğü in vitro hücre kültürü veya in vivo hayvan çalışmalarında, E.granulosus'un direkt veya indirekt olarak anti-kanser etki gösterdiği sonucuna varılmıştır. Laktat dehidrogenaz (LDH) aktivitesinin ve hücre sayısının değerlendirmeye alındığı bir çalışmada hidatik kist protoskolekslerinin in vitro ortamda WEHI-164 fibrosarkom hücrelerinin ölümünü indükleyebileceği gösterilmiştir $^{17}$. Ancak protoskolekslerin hangi mekanizma ile hücre ölümüne neden olduğu veya $\mathrm{LDH}$ aktivitesinde gözlenen değişimin olası mekanizması araştırılmamıştır. CT26 kolon kanseri fare modelinde gerçekleştirilen başka bir in vivo çalışmada, hidatik kist sıvısıyla aşılanan farelerde, solid tümör gelişiminin inhibe olduğu bildirilmiştir ${ }^{18}$. Özellikle, protoskoleks boşaltım/salgılama ("excretory/secretory, ES") molekülleri olmak üzere farklı hidatik moleküller (laminar ve germinal tabaka molekülleri ve hidatik sıvı molekülleri) ile yapılan uygulamanın HeLa hücre kültüründe ölü hücre sayısını artırabildiği ve/ veya canlı hücre sayısını azaltabildiği; Vero hücre kültüründe ise ne ölü hücre sayısında ne de canlı hücre sayısında bir değişime yol açtığı gözlemlenmiştir ${ }^{19}$. Yakın zamanda yayımlanan araştırmalarda, E.granulosus onkosferinde yüksek oranda eksprese olan, yüksek kimotripsin aktivitesine sahip bir nötrofil elastaz inhibitörü (Kunitz tip proteaz inhibitörü) EgKI-1'in, in vitro koşullarda normal hücre büyümesini etkilemeden, birçok insan kaynakIı malignant hücre büyümesini ve göçünü inhibe edebileceği gösterilmiştir. Muhtemel mekanizma olarak hücre döngüsünün bozulması sonucu kanser hücrelerinin apoptozunun indüklendiği öne sürülmüştür ${ }^{20,21}$. KE hastalarının serumları, NCl-H209/An1 insan akciğer küçük hücreli karsinom hücre hattı için sitotoksik olmasına karşın fibroblast hücreleri üzerinde hiçbir etki göstermemiştir ${ }^{22}$. Birçok çalışma, E.granulosus'un anti-kanser etkisini göstermiş olmasına karşın altta yatan moleküler mekanizmalar hala belirsizdir ${ }^{4}$.

Çalışmamızda, A549 insan akciğer adenokarsinom hücre hattı ve BEAS-2B sağlıklı akciğer epitelyal hücre hattı kullanılmıştır. Literatürde hiçbir çalışmada daha önce değerlendirilmemiş olan apoptoz mekanizmasının düzenleyicileri incelenmiştir. Uygulama öncesi hücreler BAX, BCL-2 ve p53 gen ekspresyonları açısından incelendiğinde, sağlıklı hücrelere (BEAS-2B) oranla A549 hücre hattında düşük p53 ve bununla bağlantılı olarak düşük BAX/BCL-2 (> 0.05) oranı tespit edilmiştir. BCL-2 ailesi, hücre sağ kalımını (örn.: $B C L-2, B C L-H L$ ve $M C L-1$ ) ve hücre ölümünü destekleyen (örn.: BAX, BAK ve BCL-XS) 
üyelerden meydana gelmektedir. p53, BCL-2'nin ekspresyonunda azalmaya ve BAX'ın ekspresyonunda artışa neden olarak hücrelerin apoptoza duyarlılığını kontrol edebilmektedir. BAX ve BCL-2 apoptozun en iyi bilinen düzenleyicilerinden olup, bu proteinlerin apoptoz kontrolünde uyguladıkları açık antagonistik etki, BAX/BCL-2 proteinlerinin hücre içi oranı apoptoz duyarlılığının hücresel bir belirteci olarak tanımlanmaktadır ${ }^{23}$. Apoptotik sinyale yanıt veren bir hücre, bu kavrama göre, yüksek BAX/BCL-2 oranına sahipken, kemoterapötik ilaçlar, radyasyon, hipoksi gibi çok çeşitli hücre ölümü uyaranlarına daha duyarlı olacaktır ${ }^{24}$. Çalışmamızda, BEAS-2B ve A549 hücre hatlarına en sık rastlanan genotip olan G1 genotipine ait hidatik kist sıvısı uygulanmış ve kist sıvısının sağlıklı (BEAS-2B) ve kanser (A549) hücre hatlarında konsantrasyondan bağımsız olarak hücre canlılığını ve proliferasyonu etkilemediği tespit edilmiştir. Daha sonrasında ek olarak bu uygulamanın hücrede apoptotik yolakta (BAX, BCL-2 ve p53 gen ekspresyonları açısından) değişikliğe neden olup olmadığı araştırılmıştır. Sonuç olarak, uygulama sonrasında p53 ekspresyonu ve BAX/BCL-2 oranında istatistiksel olarak anlamlı değişiklik olduğu gösterilmiştir. Bu doğrultuda, hidatik kist sıvısı uygulaması BCL-2'nin aktivitesini belirgin bir şekilde azaltmış ve p53'ün aktivitesinde artışa neden olmuş ve BAX/BCL-2 oranını bağıl olarak $0.05<$ seviyesinden $4<$ oranına çıkartmıştır.

Bu çalışmanın sonuçları, hidatik kist sıvısı uygulamasının doğrudan olarak hücre ölümüne neden olmamakla birlikte A549 kanser hücre hattını apoptoza karşı dayanıklı olma durumunu değiştirip duyarlı hale getirdiğini ilk kez göstermiş ve hidatik kist sıvısının apoptotik yolaktaki olası mekanizmasına ışık tutmuştur.

\section{TEŞEKKÜR}

Mezbahadan toplanan hidatik kist sıvısının sağlanması konusunda desteklerini esirgemeyen Doç. Dr. Salih Maçin ve ekibine teşekkür ederiz.

\section{ETIK KURUL ONAYI}

Bu çalışma için, ticari olarak elde edilen hücre hatları kullanılarak hücre kültürü ve mezbahadan elde edilen hidatik kist sıvısı kullanılmış olması nedeniyle, etik kurul onayı gerekmemektedir.

\section{ÇIKAR ÇATIŞMASI}

Yazarlar bu makale ile ilgili herhangi bir çıkar çatışması bildirmemişlerdir.

\section{KAYNAKLAR}

1. Rook GA, Dalgleish A. Infection, immunoregulation and cancer. Immunol Rev 2011; 240(1): 141-59.

2. Oikonomopoulou K, Brinc D, Kyriacou K, Diamandis EP. Infection and cancer: revaluation of the hygiene hypothesis. Clin Cancer Res 2013; 19(11): 2834-41.

3. Pisani P, Parkin DM, Muñoz N, Ferlay J. Cancer and infection: estimates of the attributable fraction in 1990. Cancer Epidemiol Biomarkers Prev 1997; 6(6): 387-400.

4. Guan W, Zhang X, Wang X, Lu S, Yin J, Zhang J. Employing parasite against cancer: a lesson from the canine tapeworm echinococcus granulocus. Front Pharmacol 2019; 10: 1137. 
5. Ranasinghe SL, McManus DP. Echinococcus granulosus: cure for cancer revisited. Front Med (Lausanne) 2018; 5: 60.

6. Kang YJ, Jo JO, Cho MK, Yu HS, Leem SH, Song KS, et al. Trichinella spiralis infection reduces tumor growth and metastasis of B16-F10 melanoma cells. Vet Parasitol 2013; 196(1-2): 106-13.

7. Eckert J, Gemmell MA, Meslin Fo-X, Pawlowski ZS, World Health Organizattion. WHO/OIE manual on echinococcosis in humans and animals: a public health problem of global concern/edited by J. Eckert. In: Paris, France: World Organisation for Animal Health; 2001.

8. Deplazes P, Rinaldi L, Alvarez Rojas CA, Torgerson PR, Harandi MF, Romig T, et al. Global distribution of alveolar and cystic echinococcosis. Adv Parasitol 2017; 95: 315-493.

9. Tamarozzi F, Akhan O, Cretu CM, Vutova K, Akinci D, Chipeva R, et al. Prevalence of abdominal cystic echinococcosis in rural Bulgaria, Romania, and Turkey: a cross-sectional, ultrasound-based, population study from the HERACLES project. Lancet Infect Dis 2018; 18(7): 769-78.

10. Altintas N, Topluoglu S, Yıldırım A, Uslu H, Ekşi F, Ok ÜZ, et al. Current Situation Report of Cystic Echinococcosis in Turkey. Turk Hij Tcr Biyol Derg 2020;77 (3): 1-51.

11. Giri S, Parija SC. A review on diagnostic and preventive aspects of cystic echinococcosis and human cysticercosis. Trop Parasitol 2012; 2(2): 99-108.

12. Pawlowski Z, Eckert J, Vuitton DA, Ammann R, Kern P, Craig P, et al. Echinococcosis in humans: clinical aspects, diagnosis and treatment. 2001.

13. Sayek I. Kist Hidatik Hastalığı: Klinik Yönleri, 141-7. Hidatidoloji Derneği Yayınları. 2004, İzmir.

14. Akgül H, Tez M, Unal AE, Keşkek M, Sayek I, Ozçelik T. Echinococcus against cancer: why not? Cancer 2003; 98(9): 1999-2000.

15. Nakao M, Sako Y, Yokoyama N, Fukunaga M, Ito A. Mitochondrial genetic code in cestodes. Mol Biochem Parasitol 2000; 111(2): 415-24.

16. Oikonomopoulou K, Yu H, Wang Z, Vasiliou SK, Brinc D, Christofi G, et al. Association between Echinococcus granulosus infection and cancer risk - a pilot study in Cyprus. Clin Chem Lab Med 2016; 54(12): $1955-61$.

17. Yousofi Darani H, Soozangar N, Khorami S, Taji F, Yousofi M, Shirzad H. Hydatid Cyst Protoscolices Induce Cell Death in WEHI-164 Fibrosarcoma Cells and Inhibit the Proliferation of Baby Hamster Kidney Fibroblasts In Vitro. J Parasitol Res 2012; 2012: 304183.

18. Berriel E, Russo S, Monin L, Festari MF, Berois N, Fernández G, et al. Antitumor activity of human hydatid cyst fluid in a murine model of colon cancer. Scientific World Journal 2013; 2013: 230176.

19. Aref N, Shirzad H, Yousefi M, Yousofi Darani H. Effect of different hydatid cyst molecules on Hela and Vero cell lines growth in vitro. Journal of Immunodeficiency \& Disorders 2013; 02.

20. Ranasinghe SL, Boyle GM, Fischer K, Potriquet J, Mulvenna JP, McManus DP. Kunitz type protease inhibitor EgKI-1 from the canine tapeworm Echinococcus granulosus as a promising therapeutic against breast cancer. PLoS One 2018; 13(8): e0200433.

21. Ranasinghe SL, Fischer K, Zhang W, Gobert GN, McManus DP. Cloning and Characterization of two potent kunitz type protease inhibitors from Echinococcus granulosus. PLoS Negl Trop Dis 2015; 9(12): e0004268.

22. Karadayi S, Arslan S, Sumer Z, Turan M, Sumer H, Karadayi K. Does hydatid disease have protective effects against lung cancer? Mol Biol Rep 2013; 40(8): 4701-4.

23. Kosmider B, Wojcik I, Osiecka R, Bartkowiak J, Zyner E, Ochocki J, et al. Enhanced P53 and BAX gene expression and apoptosis in A549 cells by cis-Pt(II) complex of 3-aminoflavone in comparison with cis-DDP. Invest New Drugs 2005; 23(4): 287-97.

24. Perlman H, Zhang X, Chen MW, Walsh K, Buttyan R. An elevated bax/bcl-2 ratio corresponds with the onset of prostate epithelial cell apoptosis. Cell Death Differ 1999; 6(1): 48-54. 